\title{
ДІАГНОСТИКА ФІЗИЧНОГО СТАНУ ДІТЕЙ МОЛОДШОГО ШКІЛЬНОГО ВІКУ ЗІ СКЛАДНИМИ ПОРУШЕННЯМИ P03BИTKУ
}

Наталія Лещій, Південноукраїнський державний педагогічний університет імені К. Д. Ушинського, м. Одеса, Україна, lleschiy@ukr.net

Діти зі складними порушеннями розвитку мають свої специфрічні особливості розвитку, що потрібно враховувати під час реалізації фрізкультурно-оздоровчої роботи. Система оперативного оцінювання фрізичного розвитку і результатів фрізкультурно-оздоровчої роботи $€$ невід'ємною частиною планування та оцінювання ефективності розробленого плану корекційно-оздоровчої роботи з дітьми, які мають складні порушення розвитку. Результати проведеного дослідження свідчать про недостатність фрізичного розвитку дітей зі складними порушеннями розвитку. Встановлено, що у здорових хлопчиків значення індексу Кетле було вірогідно більше на $1,49 \mathrm{k} / \mathrm{m}^{2}(p<0,05)$ порівняно 3 хлопчиками, що мають складні порушення розвитку, екскурсії грудної клітки - на 2,9 см $(p<0,001)$, життєвої ємності легень - на 120,40 мл $(p<0,01)$, силового індексу - на 22,50 \% $(p<0,001)$. У дівчаток, що мають складні порушення розвитку, значення індексу Кетле було вірогідно менше на $1,19 \mathrm{kг} / \mathrm{M}^{2} \quad(p<0,05)$ порівняно зі здоровими однолітками, екскурсії грудної клітки - на 2,5 см $(p<0,001)$, життєвої ємності легень - на 120,60 мл $(p<0,01)$, силового індексу на $22,50 \%(p<0,001)$.

Ключові слова: фрізичний стан, діагностика, діти, складні порушення розвитку.

Наталия Лещий, Южноукраинский государственный педагогический университет имени К. Д. Ушинского, г. Одесса, Украина

Диагностика физического состояния детей младшего школьного возраста со сложными нарушениями развития

Дети со сложными нарушениями развития имеют свои специфические особенности развития, которые нужно учитывать при реализации фризкультурно-оздоровительной работы. Система оперативного оценивания фризического развития и результатов фризкультурно-оздоровительной работы является неотьемлемой частью планирования и оценки эффективности разработанного плана коррекционно-оздоровительной работы с детьми, имеющими сложные нарушения развития. Результаты проведенного исследования свидетельствуют о недостаточности физического развития детей со сложными нарушениями развития. Установлено, что у здоровых мальчиков значение индекса Кетле было достоверно больше на $1,49 \mathrm{kг} / \mathrm{M}^{2}(\mathrm{p}<0,05)$ по сравнению с мальчиками со сложными нарушениями развития, экскурсии грудной клетки - на 2,9 см $(p<0,001)$, жизненной емкости легких () Лещій Н., 2019 
на 120,40 мл $(p<0,01)$, силового индекса - на 22,50\% ( $p<0,001)$. У девочек со сложными нарушениями развития, значение индекса Кетле было достоверно меньше на $1,19 \mathrm{kг} / \mathrm{m}^{2}$ $(p<0,05)$ по сравнению со здоровыми сверстниками, экскурсии грудной клетки - на 2,5 см ( $<0,001)$, жизненной емкости легких - на 120,60 мл ( $p<0,01)$, силового индекса на $22,50 \%(p<0,001)$.

Ключевые слова: физическое состояние, диагностика, дети, сложные нарушения развития.

Nataliya Leshchii, South-Ukrainian State Pedagogical University named after K. D. Ushinskogo, Odesa, Ukraine

Diagnostics of physical condition of younger school age children with complex developmental disorders

The article deals with the problem of diagnostics of physical condition of children who have complex developmental disorders. Children with complex developmental disabilities are a special category of children with their own peculiarities, which allow them to develop in the whole integrity during the implementation of physical culture and health work. The system of operational assessment of physical development and the results of physical culture and recreational work is an integral part of planning and evaluation of the effectiveness of the developed plan of correctional and recreational work with children who have complex developmental disorders. The results of the study indicate the insufficiency of the physical development in boys and girls with complex developmental disorders. It was found that in healthy boys, the value of the Ketle index was significantly higher by $1.49 \mathrm{~kg} / \mathrm{m}^{2} \quad(p<0.05)$ as compared with boys with complex developmental disorders, chest excursion - by 2.9 $\mathrm{cm}(\mathrm{p}<0.001)$, vital capacity $-120.40 \mathrm{ml}(p<0.01)$, power index - by $22.50 \%(p<0.001)$. It has been established that Ketle index value is significantly less by $1.19 \mathrm{~kg} / \mathrm{m}^{2}(p<0.05)$ in girls with complex developmental disorders compared with control group, chest excursions by $2.5 \mathrm{~cm} \quad(p<0.001)$, vital capacity lungs - by $120.60 \mathrm{ml}(\mathrm{p}<0.01)$, power index - by $22.50 \% \quad(p<0.001)$.

Keywords: physical condition, diagnosis, children, complex developmental disorders

Постановка проблеми, аналіз досліджень та публікащій. На сучасному етапі розвитку спеціальної психології позначилася тенденція більш уважного і ретельного вивчення та аналізу структури складного дефекту з метою виявлення, опису та систематизації особливостей психофізичного розвитку дітей зі складними порушеннями розвитку [1; 4]. В Україні нині функціонує система спеціальних закладів для дітей з порушеннями психофізичного розвитку.

Діти зі складними порушеннями розвитку мають свої специфічні особливості розвитку, що потрібно враховувати під час реалізації фізкультурно-оздоровчої роботи, що дає можливість їм розвиватися у всій цілісності $[2 ; 3 ; 5 ; 7]$. Отже, до складних порушень відносять поєднання двох або більше первинних психофізичних порушень, що однаковою мірою визначають структуру аномального розвитку та труднощі соціальної адаптації дитини. Означені порушення зумовлюють відхилення від нормального ходу розвитку та пов'язані з порушення-

«ОСОБЛИВА ДИТИНА: навчання і виховання», № 3, 2019 77 
ми різних систем, кожне з яких існує в цьому комплексі з характерними для нього особливостями.

Згідно з даними Н. Назарової [6], сучасні дослідники залежно від структури порушення поділяють дітей з поєднаними порушеннями на три основні групи:

- до першої входять діти з двома вираженими психофізичними порушеннями, кожне з яких може викликати аномалію розвитку, наприклад, сліпоглухі, розумово відсталі глухі, слабочуючі з первинною затримкою психічного розвитку;

- до другої групи входять діти, що мають одне істотне психофізичне порушення (провідне) і супутне йому інше порушення, виражене в слабкому ступені, яке помітно обтяжує перебіг хвороби, наприклад, розумово відсталі діти 3 невеликим зниженням слуху;

- до третьої групи входять діти з так званими комплексними порушеннями, коли є три і більше первинних порушень, виражених у різному ступені і призводять до значних відхилень у розвитку дитини, наприклад, розумово відсталі, слабко зорі, глухі діти.

На нашу думку, найскладнішим у педагогічному плані поєднанням є поєднання первинних порушень опорно-рухового апарату, інтелекту та сенсорних функцій, що потребує диференційованого підходу до планування та проведення психолого-педагогічної корекції.

Своєрідність складних порушень, у яких поєднуються розлади зору, слуху, інтелектуальна недостатність, порушення опорно-рухової системи, мовленневі порушення потребує глибокого наукового обгрунтування загального процесу диференційованого навчання і виховання. Всебічне вивчення особливостей розвитку таких дітей буде сприяти уточненню принципів виділення різних дитячих категорій, направлення дітей в особливі групи і класи, а також встановлення більш дієвих шляхів корекційно-педагогічної роботи.

Система оперативного оцінювання психофізичного розвитку i контролю результатів фізкультурно-оздоровчої роботи є невід'ємною частиною планування та оцінювання ефективності розробленого плану корекційно-оздоровчої роботи 3 дітьми, які мають складні порушення розвитку $[4,7,8]$.

3 огляду на зазначене постає актуальна проблема визначення особливостей фізичного розвитку дітей зі складними порушеннями розвитку.

Мета - визначення особливостей фізичного розвитку дітей зі складними порушеннями розвитку.

Методи дослідження: теоретичний аналіз та узагальнення науково-методичної літератури; педагогічне тестування: індекс Кетле, визначення екскурсії грудної клітки, життєвої ємності легень, життєвого індексу, силового індексу, плечового індексу; методи математичної статистики. У дослідженні брали участь 76 дітей молодшого шкільного віку зі складними порушеннями розвитку (експериментальна група), з-поміж яких 40 дівчат та 36 хлопців та 78 майже здорових дітей (контрольна група), серед яких 40 дівчат та 38 хлопців. Середній 


\section{BEKSOP TPAHROCOPMANUIII}

вік досліджуваних експериментальної групи 7,8土1,2 роки, контрольної групи $7,9 \pm 1,1$ роки. Групи були однорідними за віком та статтю.

Результати дослідження та їх обговорення. Показниками фізичного здоров’я дитини є рівень морфофізіологічного розвитку (відсутність аномалій і відхилень в анатомічній будові тіла, нормальне функціонування всіх органів та систем організму, їх ріст і розвиток), що виявляється й підтверджується віковими антропота біометричними показниками (довжина, маса тіла, об'єм грудної клітки, робота серця, органів дихання, опорно-рухового апарату, постава, тощо).

Результати дослідження фізичного розвитку хлопчиків молодшого шкільного віку представлено в таблищ 1.

Проведений розрахунок індексу Кетле в обох групах досліджуваних хлопчиків засвідчив наявність недостатньої маси тіла у дітей з важкими порушеннями розвитку, середнє значення його в експериментальній групі було вірогід-

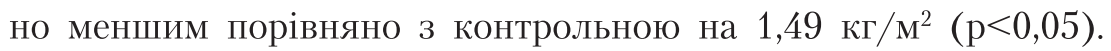

Вихідні дані екскурсії грудної клітки (таблиия 1) були також меншими за норму у дітей зі складними порушеннями розвитку, що свідчить про наявність щадного типу дихання, низькою амплітудою рухів грудної клітки, а також недостатньо тренованою дихальною мускулатурою. Значення екскурсії грудної клітки було вірогідно меншим у досліджуваних експериментальної групи порівняно $з$ контрольною на 2,9 см $(\mathrm{p}<0,001)$.

Значення життєвої ємності легень також було вірогідно меншим у дітей зі складними порушеннями розвитку порівняно зі здоровими однолітками на 120,40 мл $(\mathrm{p}<0,01)$, що свідчить про знижені адаптаційні можливості системи зовнішнього дихання та слабо розвинену силу дихальних м язів у хлопчиків із складними порушеннями розвитку.

Середній показник життєвої ємності легень в обстежуваних експериментальної групи перебував нижче норми, тоді як у досліджуваних контрольної групи - у нормі. Детальний аналіз результатів дослідження життєвої ємності легень виявив, що у 30 \% хлопчиків експериментальної групи iï значення були в нормі і в умовній нормі, у 20 \% - в легкому зниженні, у $50 \%$ - у помірному зниженні; у здорових дітей контрольної групи у 80 \% значення життєвої емності легень було в нормі і лише у 20 \% - у легкому зниженні.

Життєвий індекс свідчить про те, що у всіх групах обстежуваних дітей його фактичне значення відповідало нормативним значенням.

Проведений розрахунок силового індексу в обох групах також засвідчив його зниження у хлопчиків експериментальної групи порівняно 3 контрольною на $22,50 \%(\mathrm{p}<0,001)$. Отримані знижені показники плечового індексу в обох групах хлопчиків свідчить про наявність кіфотичної постави, однак у досліджуваних експериментальної групи плечовий індекс був на 1,19 \% (p>0,05) менше порівняно $з$ контрольною.

«ОСОБЛИВА ДИТИНА: навчання і виховання», № 3, 2019 79 


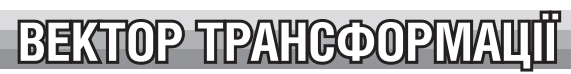

Показники фізичного розвитку хлопчиків експериментальної

Таблиия 1

та контрольної групи $(\mathrm{M} \pm \mathrm{m})$

\begin{tabular}{|l|l|l|l|}
\hline Показник, одиниці вимірювання & Експериментальна група (n=36) & $\begin{array}{c}\text { Контрольна група } \\
(\mathbf{n = 3 8})\end{array}$ & \multicolumn{1}{c|}{$\mathbf{p}$} \\
\hline Індекс Кетле, кг/м² & $15,20 \pm 0,42$ & $16,69 \pm 0,46$ & $<0,05$ \\
\hline Екскурсія грудної клітки, см & $1,90 \pm 0,33$ & $4,80 \pm 0,37$ & $<0,001$ \\
\hline Життєва ємність легень, мл & $1300,50 \pm 27,14$ & $1420,90 \pm 11,09$ & $<0,01$ \\
\hline Життєвий індекс, мл/кг & $57,00 \pm 2,02$ & $56,90 \pm 1,88$ & $>0,05$ \\
\hline Силовий індекс, \% & $37,60 \pm 2,57$ & $60,10 \pm 3,25$ & $<0,001$ \\
\hline Плечовий індекс, \% & $88,78 \pm 0,58$ & $89,97 \pm 0,83$ & $>0,05$ \\
\hline
\end{tabular}

Результати дослідження фізичного розвитку дівчаток молодшого шкільного віку представлено в таблищі 2.

Представлений розрахунок індексу Кетле в обох групах досліджуваних дівчаток засвідчив схожу тенденцію наявності недостатньої маси тіла у дітей з важкими порушеннями розвитку. Значення індексу Кетле в експериментальній групі дівчаток було вірогідно меншим порівняно з контрольною групою на 1,19 кг/м ${ }^{2}$ $(\mathrm{p}<0,05)$.

Значення екскурсії грудної клітки було також вірогідно меншим у досліджуваних експериментальної групи порівняно з контрольною на 2,5 см $(\mathrm{p}<0,001)$.

Показник життєвої ємності легень також був вірогідно меншим у дівчаток зі складними порушеннями розвитку порівняно зі здоровими однолітками на 120,60 мл $(\mathrm{p}<0,01)$, що свідчить про недостатній розвиток дихальної системи.

Таблиия 2

Показники фізичного розвитку дівчаток експериментальної та контрольної групи $(\mathrm{M} \pm \mathrm{m})$

\begin{tabular}{|c|c|c|c|}
\hline Показник, одиниці вимірювання & Експериментальна група ( $n=40)$ & $\begin{array}{c}\text { Контрольна група } \\
(\mathrm{n}=\mathbf{4 0 )}\end{array}$ & $\mathbf{p}$ \\
\hline Індекс Кетле, кг/м² & $15,10 \pm 0,47$ & $16,29 \pm 0,36$ & $<0,05$ \\
\hline Екскурсія грудної клітки, см & $2,20 \pm 0,33$ & $4,70 \pm 0,39$ & $<0,001$ \\
\hline Життєва ємність легень, мл & $1200,30 \pm 20,14$ & $1320,90 \pm 22,09$ & $<0,01$ \\
\hline Життєвий індекс, мл/кг & $53,33 \pm 2,02$ & $53,58 \pm 1,88$ & $>0,05$ \\
\hline Силовий індекс, \% & $35,60 \pm 1,57$ & $58,10 \pm 1,25$ & $<0,001$ \\
\hline Плечовий індекс, \% & $88,68 \pm 0,52$ & $89,96 \pm 0,73$ & $>0,05$ \\
\hline
\end{tabular}




\section{BEKSOP TPAHROCOPMANUIII}

Середній показник життєвої ємності легень у дівчат експериментальної групи перебував нижче норми, тоді як у досліджуваних контрольної групи - у нормі. Детальний аналіз результатів дослідження життєвої ємності легень виявив, що у 20 \% дівчат експериментальної групи ї значення були в нормі і в умовній нормі, у $30 \%$ - у легкому зниженні, у $50 \%$ - у помірному зниженні; у здорових дівчат молодшого шкільного віку у 90 \% значення життєвої ємності легень було в нормі і лише у 10 \% - у легкому зниженні.

Під час порівняння життєвого індексу між досліджуваними групами не було відзначено наявності вірогідних відмінностей. Проведений розрахунок силового індексу в обох групах також засвідчив його зниження у дівчаток експериментальної групи порівняно 3 контрольною на $22,50 \%(\mathrm{p}<0,001)$. Значення плечового індексу в досліджуваних дівчаток експериментальної групи було на 1,28 \% ( $>0,05)$ менше порівняно 3 контрольною, однак ці відмінності були статистично незначущі.

Так, отримані результати оцінювання фізичного розвитку дітей зі складними порушеннями розвитку свідчать про наявність вірогідної різниці майже за всіма досліджуваними показниками у порівнянні зі здоровими однолітками, що потребує розробки спеціальних фізкультурно-оздоровчих заходів для іх поліпшення. Саме адекватна своєчасна допомога на фізкультурно-оздоровчих заняттях сприятиме розширенню їхніх контактів з оточуючим світом, інтеграції в сучасне суспільство з метою встановлення соціалізації, а також дозволить здійснити цілеспрямований вплив на порушені функції організму дітей зі складними порушеннями, корегуючи ї у потрібному напрямі, забезпечуючи тим самим безбар'єрне середовище їх життєдіяльності.

Висновки. Результати проведеного дослідження свідчать про недостатність функціональних можливостей органів дихання, а також знижені показники фізичного розвитку в хлопчиків та дівчаток зі складними порушеннями розвитку.

Встановлено, що у здорових хлопчиків значення індексу Кетле було вірогідно більше на 1,49 кг $/ \mathrm{m}^{2}(\mathrm{p}<0,05)$ порівняно з хлопчиками, що мають складні порушення розвитку, екскурсії грудної клітки - на 2,9 см $(\mathrm{p}<0,001)$, життєвої ємності легень - на 120,40 мл ( $<00,01)$, силового індексу - на 22,50 \% $(\mathrm{p}<0,001)$.

У дівчаток, що мають складні порушення розвитку, значення індексу Кетле було вірогідно менше на 1,19 кг $/ \mathrm{m}^{2}(\mathrm{p}<0,05)$ порівняно зі здоровими однолітками, екскурсії грудної клітки - на 2,5 см (р<0,001), життєвої ємності легень на 120,60 мл $(\mathrm{p}<0,01)$, силового індексу - на 22,50\% $(\mathrm{p}<0,001)$.

Отримані результати підтверджують необхідність упровадження спеціальних фізкультурно-оздоровчих заходів для підвищення функціональних можливостей функції зовнішнього дихання, нормалізації маси тіла, силових здібностей, поліпшення адаптаційних можливостей серцево-судинної системи до фізичних навантажень, а також опірності організму.

«ОСОБЛИВА ДИТИНА: навчання і виховання», № 3, 2019 81 
Перспективи подальших пошуків передбачають впровадження експериментальної моніторингової технології фізкультурно-оздоровчої роботи в умовах навчально-реабілітаційного центру для дітей зі складними порушеннями розвитку та визначення іiі ефективності.

\section{ЛITEPATУPA}

1. Басилова T. А. Воспитание и обучение детей дошкольного возраста со сложными и множественными нарушениями. Специальная дошкольная педагогика: учеб. пособие / Т. А. Басилова. - М. : Академия, 2001. - С. 278-299.

2. Гладких Н. В. Діагностика стану розвитку загальної та дрібної моторики у дітей молодшого шкільного віку з комплексними порушеннями опорно-рухового апарату, інтелекту та зору / Н. В. Гладких // Актуальні питання корекційної освіти: зб. наук. праць: вип. 6, 2015. - Т. 2. - С. 26-41.

3. Івахненко $A$. A. Розвиток психомоторної функції глухих дітей молодшого шкільного віку засобами рухливих ігор : дис. ... канд. пед. наук : 13.00 .03 / А. А. Івахненко. - Державний заклад «Південноукраїнський національний педагогічний університет імені К. Д. Ушинського». - Одеса, 2012. - 200 с.

4. Мёдова Н. А. Обучение и развитие детей со сложными комплексными нарушениями: метод. рекомендации / Н. А. Медова. - Томск, 2013. - 44 с.

5. Миронава С. П. Корекційна психопедагогіка. Олігофренопедагогіка: підручник / С. П. Миронова. - Кам'янець-Подільський: Кам'янець-Подільський національний університет імені Івана Огієнка, 2015. - 312 с.

6. Назарова Н. М. Специальная педагогика : учебник для студ. учреждений высш. проф. образования / Н. М. Назарова. - М. : Издательский центр «Академия», 2013. - 384 c.

7. Супрун М. О. Теорія і практика корекційного навчання дітей з обмеженими розумовими можливостями в Україні (друга половина XIX - перша половина XX століття): дис. ... д-ра пед. наук : 13.00 .03 / М. О. Супрун. Інститут спеціальної педагогіки АПН України. - Київ, 2008. - 598 с.

\section{REFERENCES (TRANSLATED AND TRANSLITERATED)}

1. Basilova T. A. (2001). Education and training of preschool children with complex and multiple disorders. Special preschool pedagogy. Moscow: Akademiya. [in Russian].

2. Hladkykh N. V. (2015). Diagnosis of the state of development of general and small motility in children of junior school age with complex disorders of the musculoskeletal system, intelligence and vision. Topical issues of correctional education, 6 (2), 26-41. [in Ukrainian]. 
3. Ivakhnenko A. A. (2012). Development of the psychomotor function of deaf children of primary school age by means of outdoor games. (PhD thesis). SouthUkrainian State Pedagogical University named after K. D. Ushinskogo, Odesa. [in Ukrainian].

4. Mëdova N. A. (2013). Training and development of children with complex complex disorders: guidelines. Tomsk. [in Russian].

5. Myronava S. P. (2015). Corrective psychopedagogy. Oligophrenopedagogy: textbook. Kamianets-Podilskyi: Kamianets-Podilskyi natsionalnyi universytet imeni Ivana Ohiienka. [in Ukrainian].

6. Nazarova N. M. (2013). Special pedagogy. Moscov : Akademiya [in Russian].

7. Suprun M. O. (2008). Theory and practice of correctional education for children with disabilities in Ukraine (second half of the nineteenth and first half of the twentieth century). (PhD thesis). Institute of Special Pedagogics of the Academy of Pedagogical Sciences of Ukraine, Kyiv. [in Ukrainian]. 